\title{
Impediments to Social Development in Pakistan
}

\author{
ZAFAR H. ISMAIL
}

\section{INTRODUCTION}

The development of infrastructure and the provision of basic services in Pakistan lie in the public domain. The quality of the built infrastructure and the service offered reflect successive governments' capability as a channel for public sector funds, their role in overall financial and macro-economic planning and management, and their administrative efficiency in implementation, operations and management - in essence the extent to which they are able to adhere to the principles of good and humane governance. Good governance is generally conceived of as the judicious exercise of economic, political and administrative authority in the public and private spheres to manage a country's affairs at all levels to improve the quality of life of the people. It is a continuing process where divergent opinions and desires are satisfied through compromise and tolerance in a spirit of cooperative action for the mutual benefit of the larger whole. It has three dimensions: one, the political regime; two, the systems and procedures for exercising authority; and three, the capacity of governments [World Bank (1994); UNDP (1997); OECD (1995); Commission on Global Governance (1995)].

When Pakistan gained political freedom in August 1947, it inherited an economic and social infrastructure unable to meet the demands of the large influx of refugees from India. Five decades later, policies emphasising public investment, subsidised credit and regulated private sector development have generated strong economic growth, but failed to implement successful social development. Over the last 50 years and more Pakistan's economy, measured through its GDP, has grown by more than 10 times, an average annual growth rate of 5.1 percent. Rapid population growth, estimated to have averaged just under 3 percent annually, has resulted in real per capita increases of only 2.1 percent per year. Social development,

Zafar H. Ismail is Principal Specialist/Company Secretary and Head of the Governance, Training, Monitoring and Evaluation Unit of the Social Policy and Development Centre.

Author's Note: The views expressed here are solely those of the author as are all errors and omissions. 
measured through the Human Development Index, has not been as impressive. Table 1 shows that this has increased annually by about 1.7 percent, and by 1997 has only just more than doubled over the last five decades.

To mitigate this imbalance, Pakistan in 1992 launched the Social Action Programme (SAP) with the help of donor assistance. With rural deprivation a major problem, it was decided that SAP should have a rural focus. As well, SAP was to take an integrated approach to the four key sectors - primary education, primary health, rural water supply and population welfare. These were chosen both because they were the most basic social services required by the population and because of the obvious linkages and potential for synergy between them. In 1997-98 the second phase of SAP was launched. With the large injection of funds into the social sector was SAP able to achieve its objectives? All stakeholders would agree that generally SAP's sole claim to achievement is in enhancing the resources available to the social sectors. It has had a mixed response in the realm of institutional reform, which was to be its guiding principle. Reviews, appraisals and evaluations (SPDC; WB; ADB; Auditor General; MSU) all suggest that the programme is in jeopardy. The government itself agrees that economic and social development has not been evenly distributed throughout the country and the gap between the rich and poor has widened. The level of social development remains extremely low, particularly in the rural areas and especially among females. Unrelenting population growth has impeded improvements in the quality of life for a large segment of the population. This has, in turn, led to rising social tensions.

Table 1

Trends in Economic and Human Development in Pakistan Since Independence

\begin{tabular}{cccc}
\hline Year & Real GDP Index & $\begin{array}{c}\text { Real Per Capita } \\
\text { GDP Index }\end{array}$ & $\begin{array}{c}\text { Human Development } \\
\text { Index }\end{array}$ \\
\hline $1949-50$ & 74 & 93 & 89 \\
$1959-60$ & 100 & 100 & 100 \\
$1969-70$ & 192 & 135 & 120 \\
$1979-80$ & 308 & 160 & 131 \\
$1989-90$ & 538 & 217 & 159 \\
$1994-95$ & 714 & 245 & 172 \\
$1998-99$ & 835 & 260 & $193^{1}$ \\
Average Annual & & & \\
Growth Rate & $5.07 \%$ & $2.12 \%$ & $1.66 \%$ \\
\hline Sources: ${ }^{1}$ Pakistan (Various Issues). \\
${ }^{2}$ United Nations Development Programme (Various Issues). \\
Note: 1 for 1997.
\end{tabular}


What has led to this dichotomy in development? This paper attempts to identify the impediments to the development of the social sectors, amplify on some of them, and in the final analysis suggest a series of solutions most of which are not for the short-term.

\section{UNDERLYING CAUSES FOR POOR DEVELOPMENT}

Senior politicians and government officers are aware that the machinery of government has contributed to the present state of affairs and that the management of the resources available to Pakistan has not been sufficiently strong to obtain the best value for money. Honest and diligent officials are frustrated with systems and procedures which are cost ineffective; the populace is faced with a political and bureaucratic system which is unaccountable and is not responsive to need; the entrepreneur is faced with a set of policies which contradict each other, are counterproductive, are incoherent and designed to assist in increasing corruption and are as constant as the changing winds; and the poor are faced with a situation where their plight is not seen sympathetically. The origins of these weaknesses can be traced to the evolution of the government bureaucracy. Designed to serve the coloniser's needs and the interest's of a ruling elite, Pakistan's bureaucratic system has become increasingly corrupt and incompetent over time. In addition, because it is trained and encouraged to serve the interests of a ruling elite, rather than to respond to the changing needs of the population, the provision of social services remains seriously out of sync with the demand.

Reviews of social sector projects [Auditor General (1997); MSU (1997); WB (1998); ADB (1996, 1997); SPDC (1997, 1998, 1999)], conclude that problems stem from bad governance, are sector-wide and hinder the cost-effective delivery of services. These fall within three broad areas: firstly, legislative framework which sets the boundaries within which institutions, agencies and agents can operate and therefore addresses issues related to devolution, discretion and accountability; secondly, political structures which determine the way in which we are governed; and lastly the intertwined trio of: institutional capacity which identifies the ability of institutions, agencies and agents to make policies, ensure coherence and coordination and ensure compliance; management which addresses issues related to the proper use of systems and procedures and the mechanisms used for the development of infrastructure and the delivery of services by ensuring that there is an equitable and transparent access to goods and services and protection of public interest from private intrusion; and efficiency which addresses issues of resource generation, expenditure planning, expenditure control, regulation and overall public administration to ensure the most effective use of resources.

\section{LEGISLATIVE FRAMEWORK}

The allocation of responsibilities between various tiers of government are enunciated in the Constitution and in a large body of legislation. However, except for 
a few areas no clear-cut allocation of responsibilities is specified where more than one tier of government is involved [AERC (1990); Inbucon (1991); Ismail (1996, 1998)]. While the principle of such an overlap are implicit, that is, the highest tier is responsible for overall policy formulation and coordination of the activity across lower tiers and the lower tiers are responsible for actual implementation, this is nowhere clearly stated. Thus a number of functions are improperly addressed or are not undertaken by default. In addition, a number of functions are best performed at the lower tiers of government, because of the need to interact with beneficiaries, but have been legislatively assigned to higher tiers. This dichotomy needs to be removed.

In theory and legislatively, the provincial governments are responsible for the development of the social sector (i.e., capital investment), and are supposed to hand over the responsibility for the operation, maintenance and delivery of services to the local councils or beneficiary communities. In fact, the provincial governments are loath to transfer these responsibilities because they are a lucrative source of patronage and rents. The complex character of this fragmentation of structures and responsibility has been highlighted in a number of studies and can be seen from the matrix of some of the responsibilities for the planning, development, management, operations, maintenance, and delivery of civic and social services in the metropolitan area of Karachi shown in Appendix 1. As can be seen, all three tiers of government and civil society organisations are involved. This dichotomy of responsibility results in inappropriate procedures, poor planning, improper budgeting, financial mismanagement, and flawed personnel policies. This can to a large extent be overcome by a clearer definition of the several tiers of government so that dichotomy, fragmentation and duplication of responsibilities are removed and authority is clearly defined and demarcated.

The link between maximising benefits from investment in infrastructure and the provision of services on the one hand and the involvement of the beneficiaries in the process from start to finish has been demonstrated around the globe. This is the principal and basic tenet for the implementation of the Social Action Programme with a view to achieving the best value for money. While this is an explicit statement of the government, legislation and mechanisms to ensure that such participation is built into the process has not yet been devised adequately. To ensure that this objective is attained, the required mechanism needs to be designed and tested before the legislation needed to ensure this is drafted and enacted. One such mechanism could be the employment of Non-Governmental Organisations in the process. The involvement of NGOs in the development process and making communities aware of their rights, responsibilities and obligations has been developed to some extent, but is largely manifest as case studies or in isolated pockets with the help of bilateral donor agencies. However, this needs to be studied in depth to draw lessons for replicability generally using a mix of public sector funds and private sector entrepreneurship. 
A small but rapidly growing segment of the population's view of legislation in Pakistan is that all legislation is passed without adequate drafting skills resulting in lacunae which may be used for access to pecuniary benefits by vested interests. Moreover, there are built-in provisions for the executive to sub-legislate (make rules and regulations), powers to set aside any mandatory requirement, waive any mandatory prohibitive provisions either "for the public good" or "in the public interest" (both euphemisms for my personal pocket) without reference to any elected controlling body of individuals and/or the ability to report on actions ex-post. While these have been included to mitigate extreme cases of hardship, in reality, however, these have tended to be used indiscriminately for personal gain. In addition, discretionary quotas for access to infrastructure, services and economic opportunity provide rents to the chosen few at the cost of the exchequer. These lead to distortions and inefficiency in public institutions and are seen to be a major avenue for corruption.

Lax legislation linked to poor governance leads to, may encourages and breeds, corruption in a number of ways, for instance through bribery and extortion, influence peddling and nepotism, and fraud and embezzlement. It reduces the efficiency on which an economy depends, and by increasing the cost of investment lowers the potential return. It also reduces the government's resources and hence its capacity for investment.

As in the rest of South Asia corruption in Pakistan is unique because it occurs up-stream, it has wings which encourage flight of capital rather than wheels which encourage re-investment and it often rewards rather than punishes as the legal processes to fight corruption are weak in themselves and the lower judiciary is amenable to letting off the accused if the 'price is right'. As elsewhere, corruption has had adverse effects on human development which contributes to people's inability to fight corruption through an improvement in governance as a result of deprivation of knowledge, literacy and rights, and has also skewed public sector investment priorities which favour large visible projects where the chances for rentseeking are substantial.

At the heart of the problem lies the corruption equation, first devised by Robert Klitgaard in 1988:

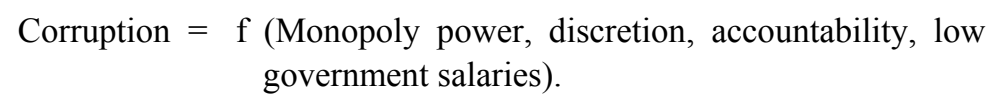

The combination of monopoly power and discretion alone is a disastrous combination. When linked to the absence of accountability and low legal earnings they become more than just lethal. Studies in Pakistan [AERC (1990); Inbucon (1993); Ismail (1996, 1998); ADB (1996)] have concluded that most, if not all, laws, rules and regulations exist only to create an environment for corruption. Some have even suggested that they actually encourage corruption both implicitly and explicitly 
because of the built in inconsistencies and contradictions. They create monopolies because power is centralised and they provide immense discretion to set aside any law regulation and rule in the public interest.

One obvious mechanism to eliminate corruption would be to review legislation which helps breed corruption, such as through creating monopoly power, permitting discretion without checks and balances, exercising authority without responsibility. Parallel to this should be an effort to reform the judicial system generally. Another mechanism would be to introduce legislation which is effectively implemented through an impartial and independent authority (with substantial representation from civil society and the senior members of the judiciary) with exemplary punishment. Corresponding changes in the laws of evidence and trial should allow for flexibility in procedures and rigour of evidence. The double standards prevalent in the developed world, particularly the safe havens of Switzerland, Liechtenstein, the Cayman Islands and the Bahamas, and now also the United States of America and the United Kingdom impose stiff legal challenges to the laundering of money generated from drugs, but a similar treatment to bribes, extortion, embezzlement and fraud is conspicuous by its absence. This needs to be rectified urgently.

The lack of transparency in the system is typified by the budgeting and planning process itself. The budgeting and financial management procedures are obscurantist. For instance, detailed budget breakdowns are invariably not presented, expenditure decisions outside the budget framework through executive orders are normal, the failure to disclose or even to discuss military spending is the rule, the limited data on revenue collection, and the absence of detailed information on new amendments and ordinances. In the planning and development management arena, there is no civil society representation in the selection of projects, ex-ante executive approval outside the normal minimal approval processes are becoming the order of the day, and variations from approved or designed specifications are condoned by 'amenable' officials. What is required is legislated free access to information, even military spending, the inclusion of civil society in planning and development management and independent monitoring, particularly by a free and investigative media.

Pakistan requires disclosure of wealth by officials and elected representatives. Follow-up action is missing. Legislation should be enacted which provides for a mandatory cross-verification of declarations for a minimum sample of returns. Delayed and no-returns should be penalised severely. In the event that investigation reveals concealment or mis-declaration, then an independent tribunal of the senior most judges and civil society representatives drawn from professional accountants (who should be elected for three year terms) should order punishment after due process. Punishments should include, confiscation of property, jail and severance from service without benefits. 
In summary, the action needed to eliminate corruption should include the following elements nationally:

- Begin accountability from the top.

- Set up national anti-corruption commissions and appoint an independent watchdog.

- Set up exclusive corruption courts.

- End unnecessary or archaic discretionary laws.

- Enact legislation to improve accountability, ensure transparency, punish the corrupt severely and ensure time bound action.

- Require public officials to declare their assets.

- Provide immunity to informers.

- Pass a Right to Information Bill.

- Use independent private-sector auditors.

- Involve people in diagnosing corrupt systems.

- Implement core institutional reforms and repair corrupt systems.

- Ensure an active and free press.

It is also necessary that parallel action at the international level should also be undertaken so that the double standards which exist are removed. Such actions, should include:

- Making all bribes given in industrialised countries illegal.

- Ensuring that all 'illegal' money and property transactions in industrialised countries is treated at par with drug money.

- Linking aid to humane governance through a programme funding mechanism "such as under IMF's ESAF/EFF, and the World Bank's Structural Adjustment Loans or Programme Loans are structured such that circumventing any conditionality becomes nearly impossible. These provide initial bridge financing to start the process of change and specify benchmarks which are quantifiable and verifiable exogenously by third parties. They must be achieved before any subsequent tranche is released. Disbursement is either withheld or delayed pending compliance, thereby providing both the carrot and the stick to encourage the implementation of change" [SPDC (1999)].

Indeed, all stakeholders in the social sectors acknowledge that there are major deficiencies in the coverage and performance of the basic social sector infrastructure and services in both urban and rural areas resulting from the built-in weaknesses in the legislative framework stemming from the Constitution of Pakistan itself and also from the body of legislation. They further acknowledge that an enormous and complex effort is required to remedy these deficiencies. This limits the institutional changes feasible at the provincial and local levels in the short- to medium-term. 
Further, the centralisation of authority and the need to wield patronage has intentionally left communities out of the decision-making process and the accompanying operations and maintenance effort. In essence, the political structure also contributes to the lack of social development in Pakistan.

\section{POLITICAL STRUCTURES}

Politics is about the creation and distribution of power and governance is the mechanism which controls the relationship between the two extremes - the governed and the governors. The political process lies at the core of governance. This can be efficient only if elections are free and fair; the elected are accountable; authority is divided between the legislature, the bureaucracy and the judiciary; and, power is decentralised.

Unfortunately, Pakistan does not meet all of these criteria. The lethal combination of powerful personalities or families linked together by familial and economic interests, on the one hand, and weak institutions, on the other, has resulted in the subversion of law which lacks accountability, creates processes which are largely personal and informal and allow rulers to operate outside established institutional frameworks. Democracy in Pakistan is confined largely to the ballot (purchased or coerced) box-and that too for the legislatures only. Political parties do not hold elections for office. Decision-making is controlled by the powerful elite. Sovereignty is equated to powerful governments, not free citizens. Democracy has not been translated into visible benefits for the poor. Pakistan's people continue to remain, perhaps, the least well endowed amongst Asians generally with respect to literacy, health, incomes, and freedom. HDC (1999) postulates that legitimate governments are, therefore, not necessarily good governments and queries "Can people be truly free when they have no control over their destinies?" The moral foundation of Governments in Pakistan has been eroded through electoral fraud, money politics, criminalisation of the political system and increasing corruption in public life.

The same powerful families appear to be the leaders of any government in power because each branch of a family is a member of another political party and most families are related to each other through marriage. They also constitute a fair portion of the senior bureaucracy, the higher judiciary and the military as the youngest are "encouraged" to seek a career, implicitly to protect their elders from the ravages of law. Thus they control the economy, deny access to social services to the disadvantaged segments of society, and the benefits of growth have accrued to them disproportionately.

The elite power structure consists of landlords (who have a disproportionate share of seats in the legislatures and policy-making agencies in government and thereby frustrate reform), a handful of large industrialists (who cumulatively control resources which are equal to or greater than the national budget), bureaucrats (who 
have gained power as a consequence of weak political structures) and the military (who have overtly ruled for half or more of the time and covertly for considerably longer). The last of the quartet justify their rule as a consequence of a breakdown in civil rule and political governments failing to legitimise themselves.

There is a growing realisation that decentralising, or ensuring local level participation in development and service delivery is the best method of ensuring equitable growth, human development and pro-people governance. The desire for decentralisation is also fuelled by ethnic diversity. There is demand for the institution of effective local government systems, not the watered down versions which exist today. In Pakistan local government elections have been held (other than in Sindh), but have been replaced by nominated bodies ostensibly on the plea that they are corrupt. A case of the pot calling the kettle black?

The power structures and power nexus formed in the higher tiers of government are replicated at the lower levels. In Pakistan, which has a federal structure, the local councillors are the younger brethren or sons of the Members of Assemblies and the contractors are their kith and kin. Thus the benefits to be derived from decentralisation are lost. Thus decentralisation is only in form and not spirit.

Further, Pakistan portrays a confused form of federalism. It has never accepted the basic principles of federalism - the exercise of independent authority within their assigned (separated) areas. The constitution itself enshrines this situation through the overlapping of functions and authority contained in what is called the combined legislative list without specifying the bifurcation between the federal and provincial governments. The federal government has tended to usurp the authority of the lower tier and the predominance of Punjab, the largest province, in both the elected and bureaucratic institutions is a peculiar feature. There is also legislative authority to set aside state/provincial governments under exceptional circumstances.

The lower tiers of government are dependent financially on the higher tiers. In Pakistan the provinces account for 25 percent and 6 percent respectively of public expenditure and revenue. The dependence of local governments, particularly in the small towns and rural areas is even severer. The smallest local governments are totally dependent for resources on the state/provincial governments. Moreover, both inter- and intra-tier sharing of revenues is a source of acrimony. This disparity in resource generation results from the allocation of tax bases, the more buoyant (trade and income) being apportioned to the federal level. This is further exacerbated by the lack of political will to collect resources.

Efficiency is a cardinal principle for good governance and only the right responsive political structures can ensure this. Thus, this will accrue from assigning functional responsibility to that governmental organisation which is closest to the people. However, such assignment must be consistent with the efficient delivery of that service. This non-hierarchical assignment permits a more constructive and dynamic relationship. For instance, the delivery of primary health care, primary 
education, water supply and sanitation, targeted distribution of social safety benefits are best delivered through local governmental institutions.

Effective local governance can be assured only through the active participation of a representative body of elected officials which has a constitutionally assured permanence, has participatory representation (say through proportional representation and quotas for women, minorities and marginalised people), has constitutionally legislated responsibilities and authority (regulation and provision of the full range of services that can equitably meet the needs of the community), and has an assured financial resource base which is not encroached on by higher tiers of government, either directly or indirectly. Fiscal policy should clearly assign which taxes may be levied by whom, and if shared, assure a mechanism which ensures automatic credit by the Central Bank/Treasury without reference to any governmental body.

The principle that the spending agency should also be the collecting agency should govern all tax assignment between tiers of government. For instance, all property and property related taxes are normally considered to lie in the realm of local governments. Worldwide these form the base through which resources are generated for maintaining basic infrastructure and finance some of the development and operations cost of primary services. In most of South Asia these have been encroached upon by the higher tiers of government and assessing and collecting responsibilities have been usurped by these higher spheres. These responsibilities should be shifted down to ensure an assured, stable and buoyant revenue source and also prudent expenditure management.

To ensure adequate funding for capital works, the larger local governmental organisations should also be assured access to capital markets. In Pakistan particularly, local governments should not be dependent on a system of erratic grants for development purposes. These must be provided for routinely.

Accountability of both the elected and the administrative hierarchy ensures adherence to standards and goals. This should be ensured, firstly through audit by non-governmental professional audit organisations, and secondly by prosecution through an independent tribunal under a legal framework which mandates a timebound process. Accountability also requires that there should be greater transparency and openness (accessibility) in the system. This can be assured through a number of actions, such as:

- Beneficiary participation in planning (through a system of committees with beneficiary representation in addition to councillors, and backed by mandatory public hearings and advertising in the media inviting public objections).

- Participatory budgeting (involvement of councillors in the preparation of budgets in preference to the preparation by officials in isolation). 
- Involvement of the non-profit and for-profit non-governmental/private sector institutions.

- Increasing public awareness.

- Simplification of processes.

- Public participation and audit of council debates and access to information.

Operational management must conform also to standards and goals. Beneficiary participation in the setting of goals and standards should be assured through a mandatory process of public hearings by elected representatives and nominees of citizens' rights groups. Participatory planning should be seen as an opportunity and not a threat.

Weak political structures have resulted in the creation of weak institutions, the lack of efficiency from planning to delivering services, particularly in the social sectors, and poor management of resources, man, material and financial.

\section{INSTITUTIONAL CAPACITY, EFFICIENCY AND MANAGEMENT}

The full set of institutions (legislative, administrative and judicial) are transplants by the $r a j$ and, therefore, do not serve the needs and aspirations of the populace. Society in Pakistan is largely informal and based on kinship where patronage plays a major role. The general perception of the common man is: his elected representative is available only when he wants his vote; the bureaucracy and the judiciary is there to serve the rich and powerful. The judiciary has been subverted by executive power, the bureaucracy is politicised and demoralised in all of South Asia and the executive is accountable in name only. The systems are fragile, unresponsive to people's needs and corrupt. Therefore, discretion, arbitrariness and political expediency rule all decision-making. Institutions are thus weakened, transaction costs are high and misgovernance increases.

At the root of the institutional decay lie the legislatures themselves. Legislators are by their very nature expected to be watchdogs, regulators, and lawmakers. They are supposed to be representatives of civil society. Legislatures, by and large, are expected to be composed of individuals of merit and integrity. However, in Pakistan legislators generally are seen to have bought their position to power, are poorly educated (as opposed to schooled). Attendance in Parliament is poor and women representation is minimal. Debates in parliaments are endless and restricted to constituency politics only and policy and decision-making is left in the hands of an overpowering executive. This weakness in the legislatures is also due to a blurring of the separation of powers between the three pillars of state. Law-making is the responsibility of the Supreme Court also, largely through its rulings which set precedents. The bureaucracy, in parallel with the executive, continues to wield immense power over policy formulation and implementation, for instance, by legislation through 'Presidential' ordinances initiated by the bureaucracy (as many as 
125 in 1996). The judiciary has also played a role in weakening the legislature. As an example, the Supreme Court of Pakistan has permitted the dissolution of Parliament on a number of occasions.

The executive is made of the head of government, the cabinet and civil servants. While the former have tenure and are not necessarily of the highest calibre, the latter are permanent and should be of the highest calibre and above politics. The former is responsible for policy and supervising implementation, the latter is required to administer and advise. To the public it is this latter which is government. It has been argued that the most powerful civil institution of Pakistan is the bureaucracy. But they have forgotten that they are public servants and not the rulers. By their very permanence, politicians have had to influence them through patronage which has led to the erosion of them as an institution. They are an all pervasive anachronism left from the days of the raj. Their major functions continue to be economic and law and order, in both of which they have failed. The provision of social services remain neglected.

The highly layered hierarchy adds significantly to the cost of service delivery, impedes the smooth functioning of departments, and is a siphon for leakages and delays in implementation. The initial rationale may have been to either decentralise authority as much as possible, or to create a barrier between the beneficiary and the authority responsible for providing the service. Over the years, however, the concept of decentralised management and control has been seriously eroded. The creation of administrative units, latch on organisations for foreign aided projects and political patronage have all meant that today the civil service is bloated and its size is increasing. This is diametrically opposite to world trends where the size of government is shrinking. Recent studies [Pakistan (1996, 1997); WB (1999)] have indicated that a substantial part of the civil service employees are redundant. As growth has slackened public sector employment has risen, largely because this is seen to be the best avenue for employment. The composition of the civil services is also skewed in comparison to the rest of the world. In Pakistan there is one officer for 15 other staff. In Bangladesh (which only three decades ago was the eastern half of Pakistan) the ratio is 1:7. The norm of 1:3 is recommended by all agencies.

Further the quality of civil servants has been eroded because of quota-based employment. This in turn has made it easier for the politicisation of the services. Only 10 percent of intake is based on merit compared to 40 percent in Bangladesh. The sheer size of the bureaucracy makes it inefficient and wasteful. Even though real wages are lower than in the private sector and are declining, the total wage bill consumes 56 percent of the non-defence, non-interest current expenditures [WB (1999a)]. The decline in real wages has led to a consequential increase in corruption, at times in collusion with politicians. The differential in public and private sector wages has compounded this problem. Some estimates suggest that the most remunerated public sector jobs are 60 percent lower than comparable positions in the 
domestic (non-multinational) private sector. The differential increases with seniority. Thus talent is not attracted.

HDC (1999) concludes that "the institution has had to face intense political interference in the form of both coercion and patronage". Those who are loyal receive better (more "lucrative") postings and more rapid promotions. Demotion, political appointment, lateral entry, ad hoc transfers, and bureaucratic reshuffle are only a few of the mechanisms used to ensure loyalty. Large scale arbitrary termination and transfers have resulted in a further lowering of morale and neutrality. On the flip side, they exert considerable influence over politicians largely owing to the immature nature of political parties and institutions.

Even though legislation may exist which allows for an efficient allocation of responsibilities and ensuring transparency and accountability in public administration, unless institutions have the corresponding capacity and capability, no change may be forthcoming to ensure efficiency in development process and delivery of services. The public institutions in Pakistan are today faced with a multitude of shortages and shortcomings. There is a skill shortage for identifying and enunciating coherent and coordinated policies; the prevailing work ethos discourages officials from ensuring compliance; systems and procedures are cumbersome and outdated; mechanisms to ensure coordination exist but are not implementedmeetings of the secretaries' committees have not been held for years on end; there is continuous interference in day-to-day management by vested interests; staff is inadequately trained both $a b$ initio and subsequently on-job because of the very short-term assignment to posts; staff selection, posting and promotions are not merit related; and the incentive structure is designed to penalise the performers.

Some fundamentally sound administrative rules and regulations have been allowed to fall into decay or have been regularly circumvented. There is a need to return, in many cases, to the formal procedures as originally defined, but, in other cases, an opportunity should now be taken to re-draw them to reduce, if not totally remove, the opportunity and hence the temptation to by-pass them. It must be realised at the outset that any process of change affecting policies and the practices that have become entrenched over the years will be viewed with apprehension by some of those directly involved and the changes will require sensitive handling.

Central to the creation of institutional capacity is the effective decentralisation of functions. This means that financial powers, administrative authority and commensurate responsibility must be given to lower echelons but within a tight regulatory framework. The current practice of requests for supplementary grants would, therefore, have to be done away with and the current powers to authorise expenditures in excess of budget allocation would need to be exercised in the same manner as the budget allocation itself, that is by the legislature in assembly through a process of dialogue "ex-ante". 
Civil service reforms need to be introduced to make the public official answerable for his actions. The current status of "permanent non-terminable" employment must be replaced by a system where the inefficient or the corrupt can be weeded out within a short time frame. Staff skills need to be developed to use modern management techniques. Mere attendance at courses operated by civil service training institutions does not constitute training. Civil servants must be required to show absorption of training skills by results in tests and examination (as is done in the defence forces). This should help in weeding out the incompetent. With greater reliance on the private sector for the development of infrastructure and the provision of services large public sector employment is unjustified. The objective would be to, at least, reduce overall public sector employment to a third of its current size.

Efficiency can be achieved in a number of ways. One may be the use of appropriate mechanisms which ensure the greatest value for money. Other ways may include pro-active legislation (rather than retro-active) ensuring target based management, or through the use of information to analyse shortcomings and suggest ways to improve. Yet others may be the use of regulatory mechanisms which ensure that private sector provision of services and development of infrastructure does not create rents for the vested segments of society.

While private sector participation can to a large extent overcome a number of shortcomings in the development of infrastructure and in the provision of services, unless controlled and regulated it could lead to situations of monopoly and oligopoly. This would result in excessive rents accruing only to the few agents involved in the process to the detriment of the disadvantaged. The legislative framework establishes the boundaries within which the public-private partnership can take place. However, these laws will need to be translated into a workable and transparent regulatory framework. While some regulatory agencies exist, they deal largely with matters related to the corporate sectors and are only now beginning to address issues related to the environment. The existing institutions are manned largely by staff without the skills needed to ensure compliance, the knowledge and understanding needed to adapt to a rapidly changing operating environment and the systems and procedures which could generate the mutual trust between the two agents - the regulators and the entrepreneurs.

The constant interference in day-to-day management by vested interest groups also impedes the maintenance of infrastructure and delivery of services in the social sectors. The fact that elected officials are given a quota of jobs to hand out as they see fit ensures that merit plays no role in the appointment of low-level staff. There are countless examples of teachers being appointed who have neither the qualifications nor experience required. Postings and transfers are made to suit the convenience of politicians. The mandated tenure of 3 years stipulated in the Rules of Business has not been applied now for the last two decades or more. In fact, the trend in the length of service in post has been asymptotic (tending to zero) in character. 
In the past, many approaches have been tried to coordinate the actions of all parties with an interest in social development, but these have failed, and the administrative arrangements have withered away. One such example is the Secretary's Committee in each province. It was intended to be a forum to coordinate interests and plans and to review improper demands being placed by the politicians within a framework of set criteria. These committees were expected to meet at least quarterly, however the last known meetings took place in early 1988. The committees had little authority; some secretaries did not feel bound by their conclusions and ignored them.

The absence of cost-effectiveness in the whole range of actions from planning to delivery is a major impediment to the effective delivery of social services in Pakistan. Over-design, low quality construction, inappropriate technology, improper site selection, opaque tendering procedures, and asynchronous release of funds have all reduced the cost-effectiveness of infrastructure development in the social sectors. The procedures used have been developed in such a way as to serve the vested interests of those seeking rents from the system. This results in an excessive need for repairs and maintenance, which cannot be done for lack of funds. This scarcity of resources, measured as the share of non-salary expenditure of total expenditure, has been worsening over the years. It has been caused by a substantial increase in wages caused by both an increase in the numbers employed and the wage rate.

The general practice of the finance department has been to reduce expenditures on operations and maintenance (O\&M), and not question the wage bill. In the light of the resource constraints facing the public sector at all levels, increasing the cost-effectiveness of expenditures will not only help achieve social indicator targets, but also strengthen the case for allocating more funds to the social sectors. Increased cost-effectiveness can be attained in two ways: either by achieving greater output from given resources or by reducing the cost of achieving a given output.

One of the most serious problems in social service delivery is the high level of wastage, particularly when resources are scarce. Examples can best be seen in education. The net continuation ratio by year and gender at the primary level since the mid-1970s shows (Graph 1) that the continuation ratios have decreased since the beginning of the Social Action Programme in 1992-93. A plausible reason for this apparent decline may be due to one factor-the shift to private schools data for which is conspicuous by its absence. The high dropout rate can be attributed also to other factors such as poverty, the high opportunity cost of education, teacher absenteeism, poor teaching skills, inappropriate teaching methods, and the low motivation among parents to educate their children, particularly in rural areas. This suggests a need to improve the environment in schools by providing better facilities, enhancing the number of qualified teachers and making the curriculum more relevant and job-related. 


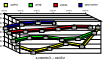

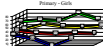

要 
Another major weakness in the systems and procedures used to manage social sector development and delivery is in the financial management arena. There appears to be no mechanism to ensure value for money or that funds are released to match demands. This is due not only to shortfalls and uncertain revenue flows, but also to the outdated systems, procedures and technology used. Budgets are prepared on the basis of historical trends rather than actual or estimated needs. The Finance Department then applies an across-the-board cut in these demands ensuring that these cuts do not impact on critical items of expenditure, such as travelling and daily allowances, the utility bills of senior staff, fuel charges and work charged staff. Because little attention is paid to routine maintenance, it usually ends up being charged to the development budget. Invariably, funds covering the purchase of supplies (e.g., books, surgical supplies, drugs, medicines, etc.) are deferred, and are released in one tranche towards the end of the year (in late May or early June). As a result, these are often purchased without using good buying practices. In any case, the amount released is not enough to meet requirements and is frequently less than the amount sanctioned. This leads to the purchase of non-standard materials and inequitable geographic distribution.

The carry forward (continuing) costs of ongoing schemes which have remained incomplete at the close of one fiscal year are carried forward to the following year(s). In 1991-92, these costs accounted for approximately 75 percent of available funds. This amount has increased to over 80 percent in 1998-99.

\section{A REFORM AGENDA}

Pakistan's impressive economic growth has not been accompanied by healthy social development. The country's progress in improving its social sectors has been slow. Over its fifty-odd years as an independent nation social development has fallen behind population growth at times. By 1991, not only was it clear that Pakistan was lagging behind its neighbours in social development, but serious internal imbalances had become evident-imbalances that cut across rural-urban lines, across genders and across provinces.

It was against this backdrop that SAP was launched. With rural deprivation a major problem, it was decided that SAP should have a rural focus. As well, SAP was to take an integrated approach to the four key sectors - primary education, primary health, rural water supply and population welfare. These were chosen both because they were the most basic social services required by the population and because of the obvious linkages and potential for synergy between them. It would appear that this has had little or no impact on the social sectors. In fact, all reviews and the government's own statistics would tend to indicate that there has been an adverse impact on primary education, and little or no impact on water and sanitation. The health sector would appear to have fared the best.

Impediments to social development fall within several broad areas: legislative framework, political structures, institutional capacity, management and efficiency. 
Some of the mechanisms which can be used to overcome these impediments follow. Most, however, require time. One must, however, realise that changing institutions and societal norms cannot be achieved at the wave of a wand. Reforms, without revolution, require time and patience.

In the legislative arena one of the major tasks that should be undertaken immediately should be a clearer definition of the several tiers of government so that dichotomy, fragmentation and duplication of responsibilities are removed and authority is clearly defined and demarcated. To contain corruption, an obvious mechanism would be to review legislation which helps breed corruption, such as through creating monopoly power, permitting discretion without checks and balances, exercises authority without responsibility. Another mechanism would be to introduce legislation which is effectively implemented through an impartial and independent authority (with substantial representation from civil society and the senior members of the judiciary). Corresponding changes in the laws of evidence and trial should allow for flexibility in procedures and rigour of evidence.

Institutional reforms should be directed to achieve effective local governance. Effective local governance can be assured only through the active participation of a representative body of elected officials which has a constitutionally assured permanence, has participatory representation (say through proportional representation and quotas for women, minorities and marginalised people), has constitutionally legislated responsibilities and authority (regulation and provision of the full range of services that can equitably meet the needs of the community), and has an assured financial resource base which is not encroached on by higher tiers of government, either directly or indirectly. Necessary constitutional changes should be undertaken. The recent change in governance structures in Pakistan may perhaps be the ideal occasion for this reform. Fiscal policy should clearly assign which taxes may be levied by whom, and if shared, assure a mechanism which ensures automatic credit by the Central Bank/Treasury without reference to any governmental body.

Accountability of both the elected and the administrative hierarchy ensures adherence to standards and goals. This should be ensured, firstly through audit by non-governmental professional audit organisations, and secondly by prosecution through an independent tribunal under a legal framework which mandates a timebound process. Accountability also requires that there should be greater transparency and openness (accessibility) in the system. This can be assured through a number of actions, such as: beneficiary participation in planning; participatory budgeting; involvement of civil sector organisations; simplification of processes; public participation and audit of council debates; and access to information

Civil service reforms need to be introduced to make the public official answerable for his actions. The current status of "permanent non-terminable" employment must be replaced by a system where the inefficient or the corrupt can be weeded out within a short time frame. Staff skills need to be developed to use modern management techniques. Mere attendance at courses operated by civil service training 
institutions does not constitute training. Civil servants must be required to show absorption of training skills by results in tests and examination (as is done in the defence forces). This should help in weeding out the incompetent. With greater reliance on the private sector for the development of infrastructure and the provision of services large public sector employment is unjustified. The objective would be to, at least, reduce overall public sector employment to a third of its current size.

Efficiency can be achieved in a number of ways. One may be the use of appropriate mechanisms which ensure the greatest value for money. Other ways may include pro-active legislation (rather than retro-active) ensuring target based management, or through the use of information to analyse shortcomings and suggest ways to improve. Yet others may be the use of regulatory mechanisms which ensure that private sector provision of services and development of infrastructure does not create rents for the vested segments of society. All or a combination of these need to be implemented. 
Appendix 1 


\section{REFERENCES}

Applied Economics Research Centre (1990) Local Government Finance and Administration in Pakistan. Karachi: Applied Economics Research Centre.

Asian Development Bank (1996) RRP:PAK 28330 Report and Recommendation of the President to the Board of Directors on a Proposed Loan to the Islamic Republic of Pakistan for the Social Action Program (Sector) Project II. Manila.

Asian Development Bank (1997) Social Sector Issues in Pakistan: An Overview. Manila: Asian Development Bank.

Auditor General of Pakistan (1998) Social Action Programme Third Party Validation : Governance Issues. Islamabad.

Auditor General of Pakistan (1998) Social Action Programme Third Party Validation : Report on Site Validation. Islamabad.

Commission on Global Governance (1995) Our Global Neighbourhood. New York: Oxford University Press.

Human Development Centre (1999) Human Development in South Asia 1999: The Crisis of Governance. Islamabad: Oxford University Press.

Ismail, Zafar H. (1996) Impediments to Improvements in Social Sectors in Pakistan. Karachi: Social Policy and Development Centre.

Ismail, Zafar H. (1998) The City of Karachi: Planning and Managing for Urban Development. Karachi: Social Policy and Development Centre.

Multi-Donor Support Units (1997) Report of the Workshop on Third Party Validation by the Office of the Auditor General of Pakistan, Islamabad.

Organisation for Economic Cooperation and Development (OECD) (1995) Participatory Development and Good Governance. Paris: Development Cooperation Guideline Series.

Pakistan, Government of (1997) Pakistan Integrated Household Survey, Round 1: 1995-96. Islamabad: Federal Bureau of Statistics.

Pakistan, Government of (1998) Access and Usage of Basic Health Services in Pakistan. Islamabad: Federal Bureau of Statistics.

Pakistan, Government of (1998) Pakistan 2010: A Vision for Knowledge-led, Just, Tolerant, Enterprising and Prosperous Society. Pakistan 2010 Programme. Islamabad: Ministry of Planning and Development.

Pakistan, Government of (1998) Pakistan Economic Outlook: Past Present and Future; Pakistan 2010 Programme. Islamabad: Ministry of Planning and Development.

Pakistan, Government of (1998) Pakistan Integrated Household Survey, Round 2: 1996-97. Islamabad: Federal Bureau of Statistics.

Pakistan, Government of (1998) Participatory Development Programme: Information and Project Proposal Form. Islamabad: Federal SAP Secretariat and Multi-Donor Suppourt Unit. 
Pakistan, Government of (1996) Planning Document: Social Action Programme Project-II (1996-2000). Federal SAP Secretariat, Planning Commission; Islamabad. November 21.

Pakistan, Government of (Various Issues) Economic Survey. Islamabad: Economic Adviser's Wing.

PE Inbucon (1993) Metropolitan Management and Budgeting Study. Egham, Surrey and Karachi.

Punjab, Government of (1998) Survey of School Management Committees in Districts D.G. Khan and Gujranwala (Punjab). Islamabad: Department of Education and the Multi-Donor Support Unit. May.

Social Policy and Development Centre (1997) Review of the Social Action Programme. Karachi: SPDC.

Social Policy and Development Centre (1998) Social Development in PakistanAnnual Review 1998. Karachi: SPDC.

Social Policy and Development Centre (1999) Social Development in PakistanAnnual Review 1999: Social Development in Economic Crisis. Karachi: Oxford University Press.

United Nations Development Programme (1997) Governance for Sustainable Human Development. New York: Management Development and Governance Division.

United Nations Development Programme (Various Issues) Human Development Report. New York: Oxford University Press.

World Bank (1994) Governance: The World Bank's Experience. Washington, D. C.

World Bank (1998) Implementation Completion Report: Pakistan-Social Action Programme Project. Poverty Reduction and Economic Management Division, South East Asian Region, Washington, D. C.

World Bank (1999) Pakistan: Civil Service Reforms. Washington, D. C.

World Bank (1999a) Pakistan: Public Expenditure Review. Washington, D. C. 